\title{
Analysis of aflatoxins and ergot alkaloids in feeds for adult equine
}

\author{
Análise de aflatoxinas e alcaloides de ergot em rações para equinos adultos \\ Análisis de aflatoxinas y alcaloides del cornezuelo de centeno en raciones para caballos adultos
}

Received: 08/22/2021 | Reviewed: 09/03/2021 | Accept: 09/07/2021 | Published: 09/09/2021

Rafael Gomes Abreu Bacelar

ORCID: https://orcid.org/0000-0002-4525-4480

Universidade Federal do Piauí, Brazil

E-mail: rafael.bacelar@hotmail.com

Márcio dos Santos Rocha

ORCID: https://orcid.org/0000-0001-6606-8268 Universidade Federal do Piaú, Brazil E-mail: msrocha@ufpi.edu.br

João Farias Sousa Junior

ORCID: https://orcid.org/0000-0002-3283-1138 Universidade Federal do Piauí, Brazil E-mail: j.f.s.j@hotmail.com

Juliana Alexandre Ianiceli

ORCID: https://orcid.org/0000-0003-0841-0226 Universidade Federal do Piauí, Brazil

E-mail: juba_dazvdo@hotmail.com

Camila Maria Coutinho Moura

ORCID: https://orcid.org/0000-0001-6983-6410 Universidade Federal do Piauí, Brazil E-mail: cahmila@live.com

Aline Maria Dourado Rodrigues ORCID: https://orcid.org/0000-0003-0566-9873 Universidade Federal do Piauí, Brazil E-mail: alinemary2@yahoo.com.br

Luciana Muratori Costa

ORCID: https://orcid.org/0000-0001-9453-8853 Universidade Federal do Piauí, Brazil E-mail: luciana.muratori@ hotmail.com

Maria Christina Sanches Muratori ORCID: https://orcid.org/0000-0002-4569-0995 Universidade Federal do Piauí, Brazil E-mail: chrismuratori@uol.com.br

\begin{abstract}
Mycotoxins are products resulting from fungi metabolism normally present in the environment and which can develop in food. The aim of this study was the fungi quantification, aflatoxin detection and investigation of ergot alkaloids occurrence in pelleted feed for adult equines during storage. The feed samples were collected from three rural properties with equideoculture activity in the city of Teresina, Piauí, Brazil. The results showed that was no significant difference $(\mathrm{p}<0.05)$ for the counting of colony-forming units $(\mathrm{CFU} / \mathrm{g})$ of filamentous fungi and yeasts in the samples. Aflatoxins B1, B2, G1 and G2 were found in acceptable amounts and the other fungal metabolites: ergometrine, griseofulvin, festuclavin, ergine and lysergol. Concluding, the results of this study demonstrate that amount of filamentous fungi and the water activity present in the original package remain constant after six days of storage. Four types of aflatoxins were found: AFB1, AFB2, AFG1, AFG2 and the Ergot alkaloids: ergine, ergometrine, festuclavine, griseofulvin and lisergol in amounts within acceptable limits. These groups of toxic compounds produced by fungi can be present in equine feed and may lead to a risk to their health.
\end{abstract}

Keywords: Fungi; Mycotoxins; Ergometrine; Griseofulvin; Festuclavin.

\section{Resumo}

As micotoxinas são produtos resultantes do metabolismo de fungos normalmente presentes no ambiente e que podem se desenvolver nos alimentos. O objetivo desse trabalho foi fazer a quantificação de fungos, detecção de aflatoxinas e pesquisar a ocorrência de alcalóides de Ergot em rações peletizadas para equinos adultos durante estocagem. As amostras de ração foram coletadas de três propriedades rurais com atividade de equideocultura da cidade de Teresina, Piauí, Brasil. Os resultados mostraram que não houve diferença significativa $(\mathrm{p}<0,05)$ para contagem de unidades formadoras de colônias (UFC/g) de fungos filamentosos e leveduras das amostras. Foram encontrados Aflatoxinas B1, B2, G1 e G2 em quantidades aceitáveis e os outros metabólitos fúngicos: ergometrina, griseofulvina, festuclavina, 
ergina e lisergol. Concluindo, os resultados deste estudo demonstram que a quantidade de fungos filamentosos e a atividade de água presentes na embalagem original permanecem constantes após seis dias de armazenamento. Quatro tipos de aflatoxinas foram encontrados: AFB1, AFB2, AFG1, AFG2 e os alcalóides do Ergot: ergina, ergometrina, festuclavina, griseofulvina e lisergol em quantidades dentro dos limites aceitáveis. Esses grupos de compostos tóxicos produzidos por fungos podem estar presentes na alimentação de equinos e podem representar um risco à saúde.

Palavras-chave: Fungos; Micotoxina; Ergometrina; Griseofulvina; Festuclavina.

\section{Resumen}

Las micotoxinas son el resultado del metabolismo de los hongos normalmente presentes en el medio ambiente y que pueden desarrollarse en los alimentos. El objetivo de este estudio fue la cuantificación de hongos, la detección de aflatoxinas y la investigación de la presencia de alcaloides del cornezuelo de centeno en piensos granulados para equinos adultos durante el almacenamiento. Las muestras de alimento se recolectaron de tres propiedades rurales con actividad de equideocultivo en la ciudad de Teresina, Piauí, Brasil. Los resultados mostraron que no hubo diferencia significativa ( $\mathrm{p}<0.05$ ) para el recuento de unidades formadoras de colonias (UFC / $\mathrm{g}$ ) de hongos filamentosos y levaduras en las muestras. Las aflatoxinas B1, B2, G1 y G2 se encontraron en cantidades aceptables y los otros metabolitos fúngicos: ergometrina, griseofulvina, festuclavina, ergina y lisergol. En conclusión, los resultados de este estudio demuestran que la cantidad de hongos filamentosos y la actividad del agua presentes en el paquete original permanecen constantes después de seis días de almacenamiento. Se encontraron cuatro tipos de aflatoxinas: AFB1, AFB2, AFG1, AFG2 y los alcaloides Ergot: ergina, ergometrina, festuclavina, griseofulvina y lisergol en cantidades dentro de límites aceptables. Estos grupos de compuestos tóxicos producidos por hongos pueden estar presentes en la alimentación de los equinos y pueden suponer un riesgo para su salud.

Palabras clave: Hongos; Micotoxina; Ergometrina; Griseofulvina; Festuclavina.

\section{Introduction}

Equines are animals that have nutritional requirements determined primarily for maintenance energy composition and also for performing physical activities. The determination of these animals feeding should be balanced and the appropriate proportions should be well-adjusted. The horses should consume daily foods with dry matter content proportional to their weight, the expected performance, as well as related to their physiological state and level of physical activity exerted (Ribeiro et al., 2009; Santos et al., 2012).

In the equine feed industry, there is an increasing demand in quality control, and this concerns several parameters related to the constitution of the food, balance, equilibrium, palatability, digestibility, and acceptability of these products by the animals. However, the main characteristic of a food is in relation to its safety, since contamination poses a risk to animal health (Hillmann et al., 2015).

Food contamination by fungi can compromise animals' health because these microorganisms that are widely distributed in the environment are able to reduce the nutritional value and, depending on the species, can produce toxic secondary metabolites that cause diseases in animals (Silva et al., 2015).

Mycotoxins are products resulting from fungi metabolism, so they are secondary metabolites that can affect both human and animal health. They are usually present in the environment in which they develop, where the most common are foods based on grains, cereals and feeds. The harvesting, processing and storage of grains used in animal feed are critical control points to obtain safe and quality feed. The environmental factors contributing to the mycotoxins occurrence are mainly temperature, environment, high humidity of the substrate associated with processing, production or storage, as well as the type of food (Ferreira, 2012; Dias et al., 2020).

Climate change favors fungal development and consequently the mycotoxins production. The study of cereals contamination that constitute the diet basis is extremely important because, besides being a tool of health surveillance, it will provide data related to the presence of mycotoxins in food and feed (FAO/WHO, 2011).

The main fungi responsible for grains deterioration in the pre-harvest and also during the storage belong to the genera: Alternaria, Aspergillus, Fusarium, Penicillium, Rhizoctonia and Stachybotrys. Among them, the genera Aspergillus, Penicillium and Fusarium stand out because they are considered of greater importance in the food and feed contamination, and 
because they are the largest producers of mycotoxins. Among the main damages caused to stored grains due to fungi development are: fermentation, changes in color, appearance of stains, alterations in odor and taste, chemical changes, losses of dry matter, reduction of germinative power and production of mycotoxins (Cardoso Filho et al., 2013).

The ergot alkaloids are important fungal secondary metabolites which production occurs in fungi sclerotia of the genus Claviceps (known as spur or ergot), especially of the species Claviceps purpurea, in which they have peptide alkaloids divided into two alkaloid structural groups of amino acids (ergotamine) and amine alkaloids and related compounds (lysergic acid and ergometrine). These compounds are responsible for the poisoning caused by the ingestion of contaminated product by these fungi, known as ergotism, and popularly called poisoning by Ergot, St. Anthony fire, holy fire, etc (Haschek et al., 2002; Mori; Nascimento junior; Miranda, 2013).

The aim of this study was the fungi quantification, aflatoxin detection and investigation of other metabolites occurrence in pelleted feed for adult equines during storage.

\section{Methodology}

\section{Collection of Samples}

The samples of pelleted feed for adult horses were collected from three rural properties (named "A, B and C") with equideoculture activity in the city of Teresina, Piaú, Brazil (WGS84: $5^{\circ} 5$ '20 "S, 42 48' 7 "W). Sampling began with one collection after the feed bag opening in each property, then two more samples were taken three days apart and repeated three times this process. Approximately $200 \mathrm{~g}$ of samples were collected directly from the feed packages which were factory sealed and were opened at the time of the first collection.

The management of the rural properties surveyed were similar and had the same form of feed supply and storage. The feed provided was pelleted with milled corn, soybean meal, laminate corn, corn bran, laminate oats, vitamins, and minerals.

After each collection, the samples were sent directly to the laboratory for microbiological analysis in University of Federal of Piauí (UFPI). The samples were aseptically divided into two equal subsamples of approximately 100g each and transferred to plastic bags of first use. One of the subsamples was stored under experimental conditions to simulate the remaining packaging in the property, being analyzed after the third and on the sixth day of the first collection. The other subsample was analyzed immediately (control).

\section{Water activity (Aw)}

Water activity (Aw) was determined using a reading apparatus Decagon Pawkit digital model. From each sample, individual portions of approximately $10 \mathrm{~g}$ were removed and were transferred to the plastic container of the apparatus. Then, after coupling of the deposit and stabilization, the panel was read directly (Decagon Devices, 2016).

\section{Isolation of microorganisms}

In the laboratory, a $25 \mathrm{~g}$ portion of the feed was aseptically transferred to a flask containing $225 \mathrm{~mL}$ of peptone water $0.1 \%$ to form the initial dilution $\left(10^{-1}\right)$. From this, serial decimal dilutions up to $10^{-3}$ were prepared (Silva et al., 2010).

From the previously prepared dilutions, aliquots of $0.1 \mathrm{~mL}$ were transferred into Petri dishes containing Potato dextrose agar (PDA) with tartaric acid 10\%. After that, the inoculum was spread all over the surface of the agar using Drigal ski handle (Pitt; Hocking, 2009). The PDA plates were incubated at $25{ }^{\circ} \mathrm{C}$ for seven days in the absence of light. The fungal counts were performed on plates that presented between 10 and 100 CFU/g (Dalcero et al., 1997; Dalcero et al., 1998). 


\section{Determination of aflatoxins and other metabolites}

For the determination of aflatoxins and other metabolites from the feed samples, only the samples collected on the first day and the sixth day of collection were selected, in order to evaluate if the samples were already contaminated with aflatoxins/other metabolites or if they were acquired by the contamination of fungi mycobiota from the feed after opening of the equine feed bag.

For the aflatoxins extraction, it was used the methodology proposed by by Soares and Rodriguez-Amaya (1989), modified by Teixeira et al. (2008).

The content determination of Aflatoxin B1, B2, G1 and G2 and of the other metabolites was performed by ultra-high performance liquid chromatography coupled to high efficiency mass spectrometry - LC-MS.

Chromatographic analyzes were performed using an Ultra Performance Liquid Chromatography (UPLC) of Shimadzu brand, equipped with a $50 \mathrm{~mm} \times 2.0 \mathrm{~mm}$ i.d., $2.2 \mu \mathrm{m}$ particle size, oven temperature maintained at $40{ }^{\circ} \mathrm{C}$. The mobile phase employed was water (Grade LC-MS) containing formic acid $0.1 \% \mathrm{~A}$ ) and methanol (Grade LC-MS) containing formic acid $0.1 \%(\mathrm{v} / \mathrm{v}$, eluent B). The flow rate employed was $200 \mu \mathrm{L} \cdot \mathrm{min}-1$, containing $5.0 \%$ of eluent B for one minute, followed by a gradient of 5.0 to $98.0 \%$ of eluent B for up to $12 \mathrm{~min}$, returning to $5.0 \%$ of eluent B for four minutes for column reconditioning.

\section{Statistical analysis}

The research was carried out using the randomized block design with factorial $3 \times 3$ (three properties, three collections). The quantitative results (counts) were transformed into logarithms for normality test, Kruskal-Wallis variance analysis and correlation, significance of $\mathrm{p}<0.05$. The qualitative results (presence) were analyzed by the Chi-square test $(\chi 2)$.

\section{Results and Discussion}

In the analyzed samples, there was no significant difference $(\mathrm{p}<0.05)$ for counting of colony-forming units $(\mathrm{CFU} / \mathrm{g})$ of filamentous fungi and yeasts, between days or storage conditions, either in the rural farms visited or in the laboratory (Table 1). That is, the amount of filamentous fungi presents in the original package remained constant until the sixth day of storage.

Table 1. Counts of filamentous fungi and yeasts in pelleted feed for equines.

\begin{tabular}{cccc}
\hline Place & \multicolumn{3}{c}{ Counts of filamentous fungi and yeasts CFU/g* } \\
\cline { 2 - 4 } & \multicolumn{3}{c}{ Rural properties storage (in days) } \\
\hline A & $\mathbf{1}^{\text {st }} \mathbf{d a y}$ & $\mathbf{3}^{\text {rd }}$ day & $\mathbf{6}^{\text {th }} \mathbf{d a y}^{*}$ \\
\hline B & 3,65 & 4,10 & 4,49 \\
C & 5,00 & 5,04 & 5,17 \\
\hline Averages & 4,19 & 4,55 & 4,14 \\
\hline Place & $4,28^{\text {a }}$ & $4,56^{\text {a }}$ & $4,60^{\text {a }}$ \\
\hline L & & $\mathbf{6}^{\text {th }}$ day \\
\hline B & & 3,31 & 4,43 \\
C & & 4,17 & 5,00 \\
\hline Averages & 4,51 & 3,88 \\
\hline
\end{tabular}

$\mathrm{CFU} / \mathrm{g}$ in $\log 10^{\mathrm{x}+1}=$ colony-forming units per gram in logarithms of base ten minus one; $*$ The averages followed by the same letter do not differ statistically from each other $(\mathrm{P}>0,05)$. Source: Authors. 
Good Manufacturing Practices (2016) recommends standard values for counts of filamentous fungi and yeasts in animal feed inferior than $6.00 \mathrm{CFU} / \mathrm{g}$ in $\log 10$. Thus, it can be verified that the analyzed feed samples had fungi counts within the recommended values. Contamination can be associated with sample conditions and failures in the production chain and may compromise product quality.

The values of filamentous and yeast fungus counts obtained in equine feed (Table 1) were similar to those of the experiment performed by Santos (2011), that analyzed feeds for broiler chickens, which samples presented averages between 3.0 and $5.23 \mathrm{CFU} / \mathrm{g}$ in $\log 10$. Probably because the initial contamination of the raw material was not inactivated by the pellet processing of the feed.

It was observed that there was no significant difference $(p>0.05)$ in the water activity analysis between the control group samples and the samples that were stored in the laboratory or in the rural properties (Table 2). Farmers used commercial rations packaged by the factory in low-density polyethylene packages. Due to its impermeability, this material favored that the ration maintained stable humidity until the moment of the use.

Table 2. Water activity in pelleted feed for equines.

\begin{tabular}{cccc}
\hline Place & \multicolumn{3}{c}{ Water activity (Aw) } \\
\cline { 2 - 4 } Ee & $\mathbf{1}^{\text {st }}$ day & $\mathbf{3}^{\text {rd }}$ day & $\mathbf{6}^{\text {th }}$ day \\
\hline A & $0,67 \pm 0,02$ & $0,67 \pm 0,03$ & $0,67 \pm 0,03$ \\
B & $0,67 \pm 0,04$ & $0,70 \pm 0,04$ & $0,69 \pm 0,02$ \\
C & $0,73 \pm 0,01$ & $0,62 \pm 0,01$ & $0,68 \pm 0,04$ \\
\hline Averages & $0,69^{\text {a }}$ & $0,66^{\text {a }}$ & $0,68^{\text {a }}$ \\
\hline Place & & Laboratory storage (Control) (in days) & \\
\hline A & & $\mathbf{3}^{\text {rd }}$ day & $\mathbf{6}^{\text {th }}$ day \\
\hline B & & $0,67 \pm 0,02$ & $0,67 \pm 0,02$ \\
C & & $0,66 \pm 0,04$ & $0,66 \pm 0,04$ \\
\hline Averages & $0,70 \pm 0,03$ & $0,70 \pm 0,01$ \\
\hline
\end{tabular}

The averages followed by the same letter do not differ statistically from each other, by the Normality Test $(\mathrm{p}<0,05)$. The mean comparison test was not applied because the interaction F was not significant. Source: Authors.

The water activity (Aw) is related to the amount of water molecules available in the substrate particles, essential for the synthesis of microorganisms. In general, the minimal Aw for the growth of filamentous fungi is 0.80 ; for yeast is 0.88 ; for xerophilic fungi and osmofilic yeasts is 0,61 (Pinto et al., 2006; Melo Filho; Vasconcelos, 2011). In the experiment by Gabbi et al. (2011), it was observed Aw values ranging from 0.61 to 0.70 in the equine feed samples. These values were close to those of the analyzed feed samples in which the values ranged from 0.66 to 0.73 (Table 2). These Aw levels disfavored the growth of most of the fungi, however the xerophilic fungi and osmofilic yeasts would be able to develop in the feeds studied.

In the analyzed samples, four types of aflatoxins were present: AFB1, AFB2, AFG1, AFG2 (Table 3). 
Table 3. Detected levels of aflatoxins $(\mu \mathrm{g} / \mathrm{kg})$ in pelleted feed samples for equines.

\begin{tabular}{|c|c|c|c|c|c|}
\hline \multirow{2}{*}{ Sample } & \multicolumn{4}{|c|}{ Aflatoxins $(\mu \mathrm{g} / \mathrm{Kg})$} & \multirow{2}{*}{ Total $(\mu \mathrm{g} / \mathrm{Kg})$} \\
\hline & AFB1 & AFB2 & AFG1 & AFG2 & \\
\hline A1 & ND & ND & ND & ND & ND \\
\hline A2 & ND & ND & ND & ND & ND \\
\hline A3 & ND & ND & ND & ND & ND \\
\hline A4 & ND & ND & ND & ND & ND \\
\hline A5 & ND & 2,5 & ND & ND & 2,5 \\
\hline A6 & ND & 0,9 & ND & ND & 0,9 \\
\hline A7 & ND & ND & ND & ND & ND \\
\hline A8 & ND & 0,5 & ND & ND & 0,5 \\
\hline A9 & ND & ND & ND & ND & ND \\
\hline A10 & ND & ND & ND & ND & ND \\
\hline A11 & ND & ND & ND & ND & ND \\
\hline A12 & ND & ND & ND & 0,1 & 0,1 \\
\hline A13 & 0,2 & ND & ND & 1,6 & 1,8 \\
\hline A14 & ND & 3,1 & ND & ND & 3,1 \\
\hline A15 & ND & ND & ND & 1,1 & 1,1 \\
\hline A16 & 0,7 & ND & ND & 3,1 & 3,8 \\
\hline A17 & ND & ND & ND & 2,7 & 2,7 \\
\hline A18 & ND & 2,2 & 0,9 & ND & 3,1 \\
\hline
\end{tabular}

ND: not detected. AF: Aflatoxins. Source: Authors.

According to the results obtained (Table 3), 10 samples (55\%) showed the presence of aflatoxins: two samples with AFB1 (11\%), five samples with AFB2 (27\%), one sample with AFG1 (5.5\%), and five samples with AFG2 (27\%). It also can be observed that three samples contained more than one type of aflatoxin. Given the results, the presence of aflatoxins in the samples can probably be explained by favorable conditions for the development of the mycotoxin-producing fungi in the evaluated periods and storage conditions, and the fungal growth in the samples may also be inherent to the intrinsic contamination from the feed raw material.

European Union legislation uses the recommendation for aflatoxin B1 levels at a maximum of $20 \mathrm{ppb}$ for animal feeds, except for young animals (EU, 2002). The Food and Drug Administration (2001) established the maximum acceptable limits in food for the sum of Aflatoxins (B1, B2, G1 and G2) at $20 \mu \mathrm{g} / \mathrm{kg}$. In the samples evaluated, the quantifications were relatively low, ranging from 0.1 to $3.1 \mu \mathrm{g} / \mathrm{kg}$ between samples, and the sum of total aflatoxins $(\mathrm{B} 1+\mathrm{B} 2+\mathrm{G} 1+\mathrm{G} 2)$ with a variation of 0.1 to 3,8 . It means that all samples are within the parameters established by current legislation.

The results showed that the rural property " $\mathrm{C}$ " had the largest number of aflatoxins contaminated samples, representing six samples. The rural properties "A" and "B", each had two samples with aflatoxin. The large percentage in the rural property " $\mathrm{C}$ " reflects the feed quality and the storage conditions.

The feed sample (16) of the rural property "A" presented the highest levels of aflatoxin quantification with a total of $3.8 \mu \mathrm{g} / \mathrm{kg}$, with 0.7 of AFB1 and 3.1 of AFG2 (Table 3). The figure below (Figure 1) shows the chromatogram with the AFB1 and AFG2 mycotoxin identification curve of the sample (16). this simultaneous detection of aflatoxins in the samples is indicative of the level of contamination and preservation of the sample. 
Figure 1. Chromatogram of the sample (16) with the AFB1 and AFG2 aflatoxins.

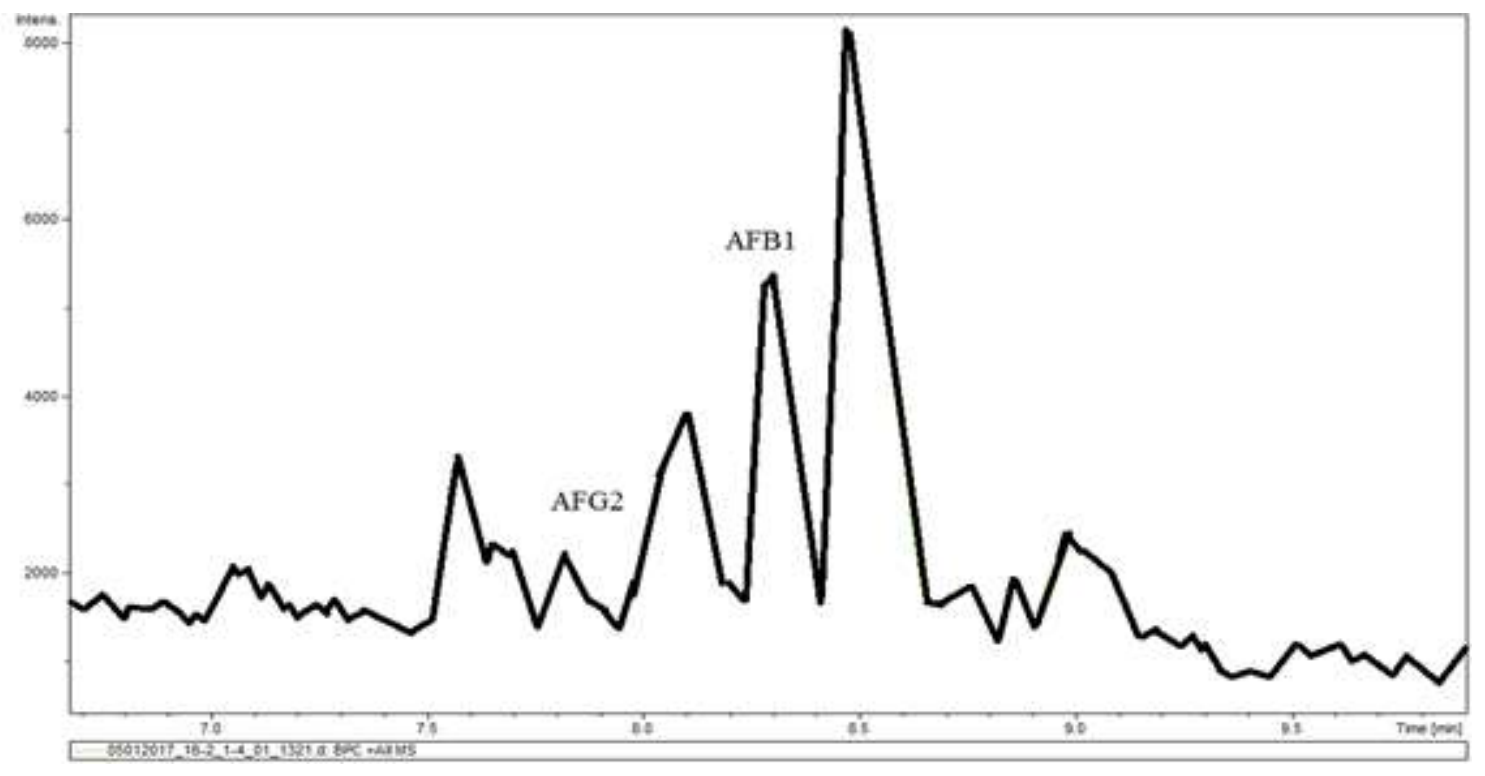

Source: Authors.

Although the aflatoxins quantification is within the limits established by the legislation, the presence of these metabolites is a risk, in which, in most cases, it can be found in foods in a very low concentration (ng/g) in a way that do not cause changes in the organoleptic properties, such as taste and odor. Therefore, it is difficult for consumers to notice, so only effective work by the competent authorities will be able to prevent possible intoxications (Caldas et al., 2002).

Other factors that show the relevance of these metabolites study in agricultural products are that food from animal origin may also be contaminated due to the consumption of contaminated food by animals, which carries indirectly a risk of human intoxication. Results of laboratory evaluations carried out in the last 10 years by the Laboratory of Mycotoxicological Analyzes (Laboratório de Análises Micotoxicológicas - LAMIC) on samples of the main ingredients used in animal nutrition (corn, wheat, rice, wheat bran, rice bran, soybean meal, silage and the feed itself) revealed an average prevalence of $41 \%$ for aflatoxins (Mallmann, 2014).

Aflatoxins have a hepatotoxic, carcinogenic and immunotoxic effect, and the liver is the target organ of aflatoxicose action in the animal and human organism. Scientific studies show that normally young animals are most affected. The main clinical signs are appetite loss, lethargy, weakness and death. Among the metabolites analyzed, aflatoxin B1 (AFB1) is considered to be the most important in the food area due to its high hepatotoxic capacity and higher concentrations in the substrates (Mallmann; Dikin, 2011).

In the research of other metabolites in the feed samples, five types of chemical compounds were identified: ergine, ergometrine, festuclavine, griseofulvin, and lisergol (Table 4). 
Table 4. Ergot alkaloids found in pelleted feed samples for equines.

\begin{tabular}{lcccc}
\hline & & \multicolumn{3}{c}{ Samples origin } \\
\hline Metabolites & Formula & Prop. A & Prop B & Prop C \\
\hline Ergine & $\mathrm{C}_{16} \mathrm{H}_{17} \mathrm{~N}_{3} \mathrm{O}$ & 13 & $\mathrm{ND}$ & 5,15 e 17 \\
Ergometrine & $\mathrm{C}_{19} \mathrm{H}_{23} \mathrm{~N}_{3} \mathrm{O}_{2}$ & 11 & $\mathrm{ND}$ & $\mathrm{ND}$ \\
Festuclavin & $\mathrm{C}_{16} \mathrm{H}_{20} \mathrm{~N}_{2}$ & $2,13 \mathrm{e} 16$ & 4,7 e 18 & 17 \\
Griseofulvin & $\mathrm{C}_{17} \mathrm{H}_{17} \mathrm{ClO}_{6}$ & $\mathrm{ND}$ & $\mathrm{ND}$ & 8 \\
Lisergol & $\mathrm{C}_{16} \mathrm{H}_{18} \mathrm{~N}_{2} \mathrm{O}$ & $\mathrm{ND}$ & $\mathrm{ND}$ & 15 \\
\hline Total & & 5 & 3 & 6 \\
\hline
\end{tabular}

ND: not detected. Prop.: rural properties. Source: Authors.

It was found in 11 samples of the different rural properties analyzed, in which some were detected in more than one sample, a total of 14 identified metabolites. The rural property $\mathrm{C}$ had the highest number of metabolites found, with six, followed by property A, with five, and property B presented in only three samples. It also important to note the presence of festuclavin in six of the samples and of ergin in four samples (Table 4). These metabolites are characterized as Ergot alkaloids and are potentially produced by mycotoxigenic plants and fungi.

The European Union encourages values for the maximum amounts of sclerotia (fungus resistance structure) tolerated in animal food of $1 \mathrm{~g} / \mathrm{kg}$, corresponding to ergot alkaloids in rye at feed concentration of approximately $1,5-6,5 \mathrm{~g} / \mathrm{kg}$ (EU, 2002).

In a study conducted by Liesener et al. (2010), in 21 rural properties creators of equines, with a total of 62 equine feed samples, showed that the samples had the presence of ergotamine alkaloids in a generic total of $30 \mathrm{mg} / \mathrm{kg}$, equivalent to $132 \%$. These values are considered high and represent a great danger to the animals that ingest in those substances in their feeding. Fayrer-hosken et al. (2013), with the objective of investigating the alkaloids effect on the reproductive functions of six stallions, provided a diet with and without toxic seeds of fescue (toxic plant rich in alkaloids) over a period of 70 days. The authors concluded that rye ergot alkaloids decreased gel free volume with consumption of high levels of alkaloids, with statistically significant effects on reproductive stallion spermogram. He concluded that feeding with the presence of toxic compounds such as alkaloids can lead animals to serious illnesses and also to death.

\section{Conclusion}

The amount of filamentous fungi and the water activity present in the original package remain constant after six days of storage. Four types of aflatoxins were found: AFB1, AFB2, AFG1, AFG2 and the Ergot alkaloids: ergine, ergometrine, festuclavine, griseofulvin and lisergol in amounts within acceptable limits. These groups of toxic compounds produced by fungi can be present in equine feed and may lead to a risk to their health. In future research I suggest the investigation of these metabolites in feed with consideration of external and internal factors.

\section{References}

Caldas, E. D., Silva, S. C., \& Oliveira, J. N (2002), Aflatoxins and ochratoxin A in food and human health risks. Rev Saude Publ, $319-323$.

Cardoso Filho, F. C., Calvet, R. M., Rosa, C. A. R., Pereira, M. M. G., Costa, A. P. R., \& Muratori, M. C. S. (2013), Monitoring of toxigenic fungi and aflatoxins in feeds used in fish farming, Ciência animal Brasileira 305-311. https://doi.org/10.5216/cab.v14i3.15414 
Dalcero, A., Magnoli, C., Chiacchiera, S., Palacios, G., \& Reynoso, M. (1997), Mycroflora and incidence of afaltoxin B1, zearalenone and deoxynivalenol in poultry feeds in Argentina. Mycopathologia, 179-184. https://doi.org/10.1023/A:1006890717758

Dalcero, A., Magnoli, C., Luna, M., Ancasi, G., Reynoso, M., Chiacchiera, S., Miazzo, R., \& Palacio G. (1998), Mycoflora and naturally ocurring mycotoxins in poultry feds in Argentina. Mycopathologia, 37-43. https://doi.org/10.1023/A:1006868002985

Decagon Devices, (2016). Inc. 2365 NE Hopkins Court, Pullman, USA, WA 9916310341.

Dias, T. F. V., Arcanjo, L. L., Costa, G. L; Souza, C. S., Lima, C. A. R. (2020), Controle de pragas e tratamento de grãos armazenados para uso em rações para animais. Research, Society and Development, [S. 1.], v. 9, n. 9, p. e739996964. https://doi.org/10.33448/rsd-v9i9.6964

EU, European Union. (2002) Directive 2002/32/EC of the European Parliament and of the Council of 7 May 2002 on undesirable substances in animal feed, $10-21$.

FAO/WHO. Food and Agricultural Organization and World Health Organization, (2011), Evaluation of certain food additives and contaminants: seventyfourth report of the Joint FAO/WHO Expert Committee on Food Additives. WHO technical report series.n. 966.

Fayrer-Hosken, R. A., Hill, N. S., Heusner, G. L., Traylor-Wiggins, W., \& Turner, K. (2013), The effects of ergot alkaloids on the breeding stallion reproductive system. Equine Veterinary Journal, 45, 44-47. https://doi.org/10.1111/evj.12164

FDA-Food and Drug Administration (2001), Federal Register. Guidance for Industry: Fumonisin levels in human foods and animal feeds. U.S. Center for Food Safety and Applied Nutrition, Center for Veterinary Medicine, November 9.

Ferreira, R. A. (2012), Swine: Practical Handbook of Creation.Viçosa, MG: Aprenda Fácil, 443 p.

Gabbi, A. M., Cypriano, L., \& Piccinin, I. (2011). Aspectos microbiológicos e físico-químicos de três rações comerciais sob diferentes condições de armazenamento. Revista Brasileira de Saúde e Produção Animal, 12, 784-793.

Good Manufacturing Practices (GMP) (2016). GMP + BA1 Specific Feed, specific feed safety limits. 84 p. URL:( https://www.gmpplus.org/pagina/9/standards.aspx) access 19 May 2020.

Haschek, W. M., Voss, K. A., \& Beasley, V. R. (2002). Selected Mycotoxins Affecting Animal and Human Health. Academic Press, 683-690. https://doi.org/10.1016/B978-012330215-1/50026-0

Hillmann, B., Soriano, V. S., Petrolli, T. G. \& Maccari, M. (2015). Microbiological analysis of diets for dogs marketed in bulk and in closed packaging, Enciclopédia biosfera, 134.

Liesener, K., Curtui, V., Dietrich, R., Märtlbauer, E., \& Usleber, E. (2010). Mycotoxins in horse feed. Mycotox Res, 23-30. http://doi.org/10.1007/s12550009-0037-8

Mallmann, C. A. (2014), Mycotoxins: how to manage risk and minimize the problem. Rev AviSite, 66.

Mallmann, C. A. \& Dikin, P. (2011). Mycotoxins and Mycotoxicoses in Swine. Special nutrients: the Mycotoxins specialist.

Melo Filho, A. B. \& Vasconcelos, M. A. S. (2011), Food Chemistry. UFRPE.78p.

Mori, C., Nascimento Junior, A., \& Miranda, M. Z., (2013). Economic and conjunctural aspects of rye culture in the world and in Brazil. Deep step. EmbrapaCNPT.

Pinto, G. A. S., Brito, E. S., Silva, F. L. H., Santos, S. F. M., \& Macedo, G. R. (2006). Fermentation in solid state an alternative for the use and valorization of agroindustrial residues. Rev. Quím. Ind., 17-20.

Pitt, J. I., \& Hocking, A. D. (2009). Fungi and spoliage (2nd ed.), Blackie academic and professional.

Ribeiro, L. B., Arruda, A. M. V., Pereia, E. S., Tonello, C. L., Barreto, J.C. (2009) Evaluation of nutrient and water intake by horses fed diets containing different agroindustrial by - products. Uruguayan. 120- 133.

Santos, E. L., Cavalcanti, M. C. A., Livia, J. E., \& Meneses, D. R. (2012). Nutritional and nutritional management of horses. Revisão. Revista eletrônica Nutritime, 1911-1943.

Santos, Y. F. M., Guimarães, C. M. M., Nunes, E. M. C. G., Calvet, R. M., Ferreira L. C. R. P., \& Muratori, M. C. S. (2011), Toxigenic fungi in feeds for broiler chicken produced in Teresina, Piauí. Higiene Alimentar, 533-534.

Silva, F. C., Chalfoun, S. M., Batista, L. R., Santos, C., \& Lima, N. (2015). Polyphase taxonomy for identification of Aspergillus flavi section: a review. Revista IFES Ciência, 18-40. https://doi.org/10.36524/ric.v1i1.235

Silva, N. (2010). Manual of methods of microbiological analysis of food and water. (4th ed.), Livraria Varela. 624 p.

Soares, L. M. V., \& Rodriguez-Amaya, D. B. (1989). Survey of aflatoxins, ochratoxin A, zearalenone, and sterigmatocystin in some Brazilian foods by using multi-toxin thin-layer chromatographic method. Journal of the Association of Official Analytical Chemists, 72:22-6.

Teixeira, A. S., Freitas-Silva, O., Godóy, R. L. O., Vargas, E. A., \& Martins, A. (2008). Analysis and quantification of aflatoxins by high performance liquid chromatography (HPLC) in Brazil nut samples. Revista Ciência da Vida, p.22-24. 